\section{Conf-950718-1}

UCRL-JC-119844

PREPRINT

\title{
The Use of Capacitive Deionization with Carbon Aerogel Electrodes to Remove Inorganic Contaminants from Water
}

\author{
J. C. Farmer \\ D. V. Fix \\ G. V. Mack \\ R. W. Pekala \\ J. F. Poco
}

This paper was prepared for submittal to the

Low Level Waste Conference

Orlando, FL

July 10-12, 1995

\section{February 17, 1995}

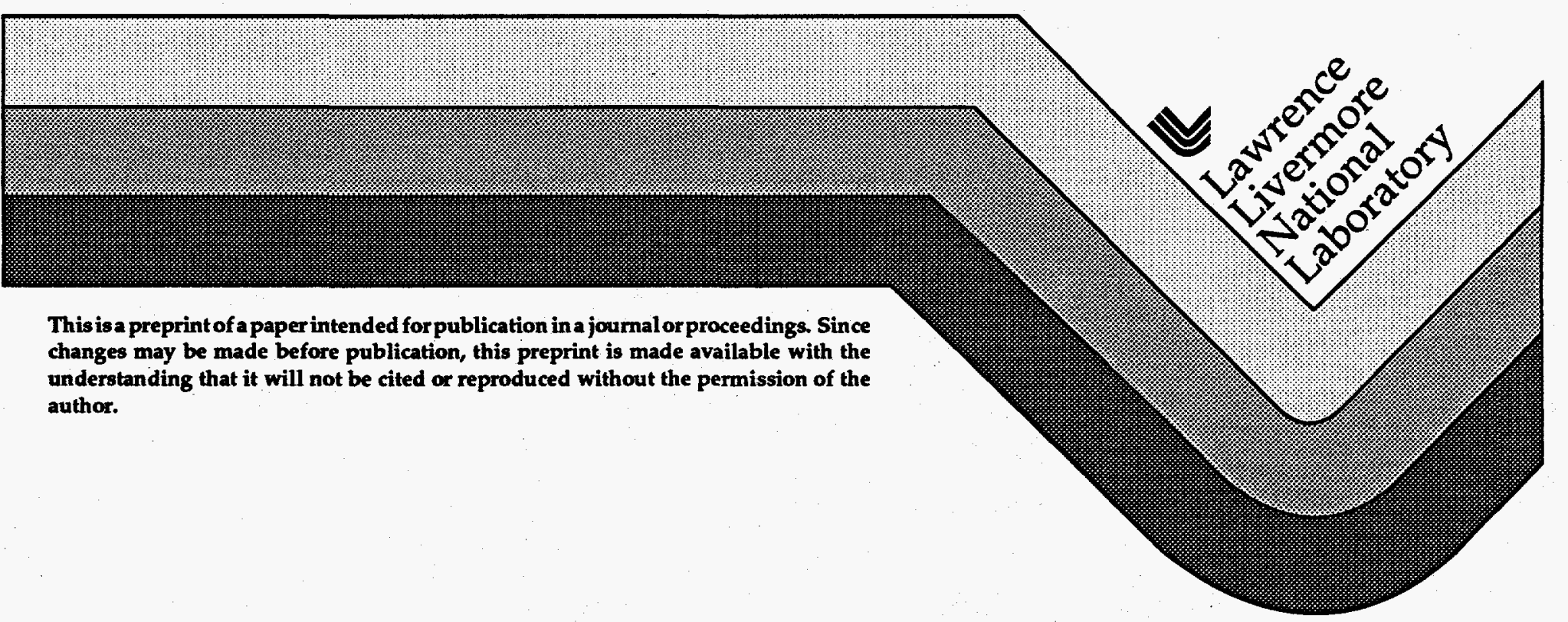




\section{DISCLAIMER}

This document was prepared as an account of work sponsored by an agency of the United States Government. Neither the United States Government nor the University of California nor any of their employees, makes any warranty, express or implied, or assumes any legal liability or responsibility for the accuracy, completeness, or usefulness of any information, apparatus, product, or process disclosed, or represents that its use would not infringe privately owned rights. Reference herein to any specific commercial product, process, or service by trade name, trademark, manufacturer, or otherwise, does not necessarily constitute or imply its endorsement, recommendation, or favoring by the United States Government or the University of California. The views and opinions of authors expressed herein do not necessarily state or reflect those of the United States Government or the University of California, and shall not be used for advertising or product endorsement purposes. 


\section{DISCLAIMER}

Portions of this document may be illegible in electronic image products. Images are produced from the best available original document. 


\title{
The Use of Capacitive Deionization with Carbon Aerogel Electrodes to Remove Inorganic Contaminants from Water
}

\author{
Joseph C. Farmer, David V. Fix, Gregory V. Mack, \\ Richard W. Pekala, and John F. Poco \\ Lawrence Livermore National Laboratory \\ 7000 East Avenue \\ Livermore, California 94551
}

\begin{abstract}
The capacitive deionization of water with a stack of carbon aerogel electrodes has been successfully demonstrated for the first time. Unlike ion exchange, one of the more conventional deionization processes, no chemicals were required for regeneration of the system. Electricity was used instead. Water with various anions and cations was pumped through the electrochemical cell. After polarization, ions were electrostatically removed from the water and held in the electric double layers formed at electrode surfaces. The water leaving the cell was purified, as desired.
\end{abstract}

\section{Introduction}

For the first time, the capacitive deionization (CDI) of water with a stack of carbon aerogel electrodes has been successfully demonstrated. An aqueous solution of $\mathrm{NaCl}$ or $\mathrm{NaNO}_{3}$ was passed through a series of electrochemical cells, each constructed from a stack of carbon aerogel electrodes having exceptionally high specific surface areas (400-1000 $\left.\mathrm{m}^{2} / \mathrm{gm}\right)$. After polarization, non-reducible and non-oxidizable ions were removed from the electrolyte by the imposed electric field and held in electric double layers formed at the surfaces of electrodes (Fig. 1). As desired, the effluent from the cell was purified water. This process is also capable of simultaneously removing a variety of other impurities. For example, dissolved heavy metals and suspended colloids can be removed by electrodeposition and electrophoresis, respectively. CDI has several potential advantages over other more conventional technologies. Unlike ion exchange, no acids, bases, or salt solutions are required for regeneration of the system. Regeneration is accomplished by electrically discharging the cells. Therefore, no secondary waste is generated. In contrast to thermal processes such as evaporation, CDI is inherently energy efficient. Since no membranes or high pressure pumps are required, CDI offers operational advantages over electrodialysis and reverse osmosis (RO).

\section{Background}

Several publications and patents have appeared that discuss the use of porous electrodes for the recovery of heavy metals from aqueous solutions [1-8]. In these cases, metallic ions are electrodeposited on the surfaces of cathodes with relatively low specific surface areas. Since deposits can be several atomic layers thick, high specific surface areas are not required. Reticulated vitreous carbon (RVC) foam has been found to be adequate for such applications. 
The first studies published on capacitive deionization appeared around 1966. Caudle et al. used porous flow-through electrodes made of activated carbon powder to desalinate water $[9,10]$. Johnson et al. conducted similar studies of reversible electrosorption, or capacitive deionization, and published their work in 1970 [11-13]. Their experimental program included verification of the theoretical basis for the process, parametric studies, and evaluation of a variety of candidate electrode materials. Johnson's work prompted Newman to develop a comprehensive theoretical model for the capacitive charging of porous carbon electrodes [14]. Unfortunately, Johnson's experimental program failed to demonstrate degradation-free electrode performance and CDI was eventually abandoned. However, preliminary cost studies did indicate that an efficient, lowcost desalination plant based upon this technology could be built if adequate durability of the electrodes could be achieved. Since this work was conducted decades before the invention of carbon aerogel electrodes, such materials were not included in the study. Several years later, work on CDI was done in Israel and published in 1983 [15-17]. They used a CDI system similar to that described by Johnson et al. for the removal of $\mathrm{NaCl}$ from water. A column was built from two separated beds of activated carbon, one serving as the anode and the other serving as the cathode. Concentration ratios as high as $1 / 100$ were attained between the top and the bottom of the column. They also developed a theoretical model to predict process performance.

Previous CDI systems used flow-through beds of activated carbon as electrodes. The beds were separated by an appropriate membrane separator. Raw water was flown along the axial direction of the carbon beds. Several important practical problems are inherent in such cells. First and foremost, activated carbon has a relatively low specific surface area. Since the carbon powder cannot be immobilized, beds must be physically separated by porous membranes. Even so, carbon particles and fines, smaller particles generated by erosion of the primary particles, can become entrained in the flow, thereby depleting the bed. Furthermore, axial flow through such packed beds results in significant pressure drop. Since these carbon electrodes are quite thick, a large potential drop also develops, thereby lowering process efficiency. Even though adjacent carbon particles may touch, intimate electrical contact may not exist. Consequently, a significant electrical resistance may develop.

Numerous supercapacitors based on various porous carbon electrodes, including carbon aerogel electrodes, have been developed for energy storage applications [18-23]. However, none of these devices were designed to permit electrolyte flow and most required membranes to physically separate the electrodes. A double-layer capacitor with a porous activated carbon electrode was developed by Nippon Electric Company of Japan [18]. An electrically conductive layer of activated carbon powder dispersed in butyl rubber, butadiene rubber, polyisoprene, or their copolymers and derivatives was coated onto one side of a current collector. High performance electrodes for double-layer capacitors based on activated carbon fibers were developed by Matsushita Electric Industrial Company [19]. NEC Corporation also developed activated carboncarbon composite electrodes for a double-layer capacitor [20]. Electrodes made of carbonized foamed phenol resin were developed by Mitsui Petrochem [21]. A wide variety of microcellular carbon foams for application in double-layer capacitors were prepared and evaluated by Sandia National Laboratory [22]. These materials were prepared by the controlled pyrolysis and carbonization of several polymers including polyacrylonitrile, polymethacrylonitrile, resorcinolformaldehyde, divinylbenzene-methacrylonitrile, furfuryl-alcohol, and cellulose polymers such as 
Rayon. The porosities of these microcellular carbon foams were established by a variety of techniques including gelation, phase separation, emulsion, aerogel-xerogel formation, and replication. An electrolytic double-layer capacitor for energy storage based carbon aerogel electrodes was also developed by Lawrence Livermore National Laboratory [23]. The carbon aerogel electrodes used in this device had very high specific surface areas; ranging from 100 to $700 \mathrm{~m}^{2} / \mathrm{cm}^{3}$ and relatively low corresponding bulk densities, ranging from 0.3 to $1.0 \mathrm{~g} / \mathrm{cm}^{3}$. These characteristics made it possible to construct a device with a very high energy density. The electrical continuity of the material permits stored energy to be released rapidly, resulting in a relatively high power density $(\sim 7.5 \mathrm{~kW} / \mathrm{kg})$. Other electrode materials have been developed for electrolytic cells, such as composites of activated carbon powder and an appropriate polymeric binder [24]. Even though these materials are made from activated carbon powders with very high specific surface areas $\left(600 \mathrm{~m}^{2} / \mathrm{gm}\right)$, much of the surface is occluded by the binder. Consequently, they do not have specific surface areas as great as carbon aerogel.

This paper discusses the capacitive deionization (CDI) of aqueous solutions with carbon aerogel electrodes. Some specific advantages of CDI with monolithic carbon aerogel electrodes include enhanced electrosorption capacity due to the immense specific surface area and complete immobilization of the porous carbon matrix. Since the specific surface area of carbon aerogel is significantly greater than that of activated carbon powder, a greater quantity of salt can be electrosorbed on carbon aerogel than on a comparable mass of activated carbon powder. Immobilization has made it possible to construct systems that do not require porous membrane separators. Unlike activated carbon powder, monolithic sheets of carbon aerogel are not entrained in the flowing fluid stream. The electrolyte flows in a channel between adjacent anodes and cathodes and does not experience the high pressure drop associated with flow through packed beds. Finally, less potential drop occurs in a thin sheet of carbon aerogel than in a relatively deep bed of activated carbon. Consequently, more ions can be electrosorbed on a unit of carbon aerogel surface area than on a comparable unit of activated carbon surface area. In deep packed beds of carbon, the potential can drop to levels where the electrosorption process is not very effective.

There are several important potential applications for CDI with carbon aerogel electrodes. Ion exchange is now used as a means for removing anions and cations, including heavy metals and radioisotopes, from process and waste water in various industries. This process generates large volumes of corrosive secondary wastes that must be treated for disposal through regeneration processes. After ion exchange columns are saturated, resins must be regenerated by pumping relatively concentrated solutions of acids, bases, or salts through the columns. These solutions become contaminated with ions removed from the resins and become part of a large inventory of secondary waste. Eventually, the resins also become part of the inventory of secondary waste. During plutonium processing, resins and solutions of $\mathrm{HNO}_{3}$ become contaminated with $\mathrm{PuO}_{2}{ }^{2+}$ and other radioisotopes. In this case, every kilogram of cation exchange resin requires approximately 100 kilograms of $10 \mathrm{wt}$. $\% \mathrm{HNO}_{3}$ and 2 to 3 kilograms of rinse water for regeneration. Similarly, every kilogram of used anion exchange resin requires approximately 100 kilograms of 10 wt. $\% \mathrm{NaOH}$ and 2 to 3 kilograms of rinse water for regeneration. Given the high and increasing cost of disposal of secondary wastes in mined geological repositories, there is tremendous and still unfulfilled need for reducing, and in certain applications, eliminating the 
volume of secondary wastes.

CDI could also be used to remove inorganic ions from boiler water for fossil and nuclear power plants. A variety of dissolved inorganic ions have to be removed to prevent scaling of heat exchanger surfaces and to prevent failure due to pitting and stress corrosion cracking. CDI could also be used to remove radioactive ions from the contaminated waste water of nuclear power plants before discharge. Deionizers based on columns of zeolite, silica gel, and ion exchange resins were evaluated for the removal ${ }^{137} \mathrm{Cs},{ }^{90} \mathrm{Sr}$, and ${ }^{125} \mathrm{Sb}$ from contaminated water at the Three Mile Island Nuclear Power Station Unit No. 2 [25]. As previously discussed, ion exchange columns require chemical regeneration and thereby produce large volumes of radioactive secondary waste. Eventually, the contaminated columns also become waste. Since CDI uses electrical regeneration, it seems ideal for such applications.

\section{Experimental}

Conceptually, the CDI process is very simple. After application of a voltage between two adjacent carbon aerogel electrodes, cations and anions are drawn towards the cathode and anode, respectively, as illustrated by Fig. 1 . These ions are held in the electric double layers formed at the extensive surface of the carbon aerogel electrodes until the voltage is reduced. A photograph of an actual electrode is shown in Fig. 2a. This double-sided electrode was made by gluing two sheets of a carbon aerogel composite (CAC) to both sides of a titanium plate that serves as both a current collector and a structural support for the CAC. Conductive silver epoxy was used for gluing. CAC has an exceptionally high specific surface area of $600-800 \mathrm{~m}^{2} / \mathrm{gm}$. Each sheet of CAC is $6.86 \mathrm{~cm} \times 6.86 \mathrm{~cm} \times 0.0125 \mathrm{~cm}$ and has a total active surface of approximately $2.8 \times 10^{6}$ $\mathrm{cm}^{2}$. Two orifices are located along one side of the carbon aerogel electrode and admit water to the electrode gap. A pattern of holes are located around the perimeter of the titanium plate and accommodate 12 threaded rods that hold the cell stack together. The second photograph, Fig. $2 \mathrm{~b}$, shows a lower stainless steel header with a rubber gasket and 12 threaded rods; an array of electrodes, gaskets, and spacers; and an upper stainless steel header. The assembly of these components into a stack is illustrated in the third photograph, Fig. 2c. Even electrodes serve as cathodes while odd electrodes serve as anodes. The electrodes and headers are aligned by the threaded rods. An electrode separation of $0.05 \mathrm{~cm}$ is maintained by cylindrical nylon spacers concentric with the threaded rods and a rubber compression seal. Since the orifices in each electrode alternate from one side of the stack to the other, the flow path through the stack is serpentine. The four assembled electrochemical cells visible in Fig. 3 include 192 pairs of carbon aerogel electrodes and have a total active cathodic (or anodic) surface area of approximately $1.1 \times 10^{9} \mathrm{~cm}^{2}$. Flow through the cell is generated by a programmable, magnetically-coupled, screw pump with a 304 stainless steel head. The maximum flow rate that can be achieved with this pump is $3.5 \mathrm{~L} / \mathrm{min}$. The differential pressure across a single stack (48 electrodes) is approximately $5 \mathrm{psi}$ at a flow rate of $1.7 \mathrm{~L} / \mathrm{min}$. In contrast, the differential pressure across four stacks in series (192 electrodes) is $14 \mathrm{psi}$ at a flow rate of approximately $1.5 \mathrm{~L} / \mathrm{min}$. All lines are made of Teflon and have a nominal diameter of $1 / 4$ inch. The cells are polarized by programmable power supplies that have a voltage range of 0 to $12 \mathrm{~V}$ or a current range of 0 to $60 \mathrm{~A}$. As shown in Fig. 4, sensors are placed on the inlet and outlet lines of the electrode stack. Electrical conductivity, pH, individual ion concentrations, and temperature are continuously monitored. A computerized data 
acquisition system logs important operating parameters such as voltage, current, conductivity, $\mathrm{pH}$, and temperature. Data acquisition system is based on an Intel 486DX-33 microprocessor, a National Instruments 8-channel A/D converter, and LabTech Notebook data acquisition software for Microsoft Windows.

As previously discussed, electrodes are made from thin sheets of CAC glued to titanium plates with conductive epoxy. Carbon aerogels were developed at Lawrence Livermore National Laboratory and are synthesized by the polycondensation of resorcinol and formaldehyde in a slightly basic medium, followed by supercritical drying and pyrolysis in an inert atmosphere $[26,27]$. Sheets of CAC are made by impregnating carbon cloth with the resorcinol-formaldehyde solution and then carbonizing. This fabrication process results in unique open-cell carbon foams that have high porosities, high specific surface areas $\left(400-1000 \mathrm{~m}^{2} / \mathrm{g}\right)$, ultrafine cell and pore sizes $(\leq 50 \mathrm{~nm})$, and a solid matrix composed of interconnected colloidal-like particles or fibrous chains with characteristic diameters of $10 \mathrm{~nm}$. The porosity and surface area of aerogels can be controlled over a broad range, while the pore size and particle size can be tailored at the nanometer scale.

Initial parametric studies were performed with solutions of $\mathrm{NaCl}$ and $\mathrm{NaNO}_{3}$ in water. In each case, experiments were performed over a broad range of solution conductivity and cell voltage. Conductivities ranged from 7.5 to $100 \mu \mathrm{mho} / \mathrm{cm}$ and voltage levels were $0.0,0.4,0.6,0.7,0.8$, 1.0 , and $1.2 \mathrm{~V}$. Batch-mode experiments were done by continuously recycling $4.0 \mathrm{~L}$ of electrolyte at a flow rate of $1.0 \mathrm{~L} / \mathrm{min}$. Single-pass experiments were done by pumping $20 \mathrm{~L}$ of electrolyte through the electrode stack at flow rate of $15 \mathrm{ml} / \mathrm{min}$. In this case, there was no recycle.

\section{Results}

Tests demonstrated that $\mathrm{CDI}$ with carbon aerogel can effectively remove both $\mathrm{NaCl}$ and $\mathrm{NaNO}_{3}$ from water. Deionization was accomplished during charging, while regeneration was accomplished during discharge. The concentration and conductivity of a sodium chloride solution was cycled up and down numerous times by charging and discharging the stack. The ability of the $\mathrm{CAC}$ electrodes to remove ions from water, e.g., the electrosorption capacity, had a strong dependence on cell voltage. The best results were achieved at $1.2 \mathrm{~V}$, with relatively poor performance below $0.4 \mathrm{~V}$. No severe irreversible degradation in performance was observed after cycling the stacks several months. During experiments without recycle, a characteristic breakthrough time was observed for each salt, which is indicative of ionic selectivity.

Voltage, current, and solution conductivity data showing the periodic charging and discharging of a stack of 48 pairs of carbon aerogel electrodes during a batch-mode experiment are shown in Fig. 5. The electrolyte was a solution of $\mathrm{NaCl}$ in water and had an initial conductivity of 7.5 $\mu \mathrm{mhos} / \mathrm{cm}(7.5 \mathrm{ppm})$. Note that $\mathrm{NaCl}$ concentration is measured as conductivity and that 1 $\mu \mathrm{mho} / \mathrm{cm}$ corresponds to approximately $1 \mathrm{ppm}$. The amplitude of the applied voltage pulse was $1.0 \mathrm{~V}$, the volume of electrolyte was $1.0 \mathrm{~L}$, and the flow rate through the stack of electrodes was $1.0 \mathrm{~L} / \mathrm{min}$. From this data, it is clear that the concentration of $\mathrm{NaCl}$ drops when the electrodes are polarized. After 17.5 minutes of deionization, beginning at 2.5 minutes, the concentration of the 
$\mathrm{NaCl}$ solution dropped to approximately $1 \mu \mathrm{mho} / \mathrm{cm}$, a reduction of solution conductivity and $\mathrm{NaCl}$ concentration of approximately $85 \%$. The salt was placed back into solution by discharging the cell at 20 minutes. The regeneration was $90 \%$ complete after 10 minutes. The process was repeated reversibly for several hundred cycles. The failure of the current to decay to asymptotically to zero is believed to have been due to parasitic electrochemical reactions such as oxygen reduction. Unfortunately, the electrolyte in this experiment was not deaerated. There may also have been current leakage across the gaskets and spacers.

Experiments were conducted with a solution of $\mathrm{NaCl}$ in water that had an initial conductivity slightly greater than $100 \mu \mathrm{mho} / \mathrm{cm}$ (approximately $100 \mathrm{ppm}$ ). A stack of 192 pairs of carbon aerogel electrodes was used. During batch-mode experiments with complete recycle, the amplitude of the applied voltage pulse was $1.0 \mathrm{~V}$, the volume of electrolyte was $4.0 \mathrm{~L}$, and the flow rate through the stack of electrodes was $1.0 \mathrm{~L} / \mathrm{min}$. Voltage, current, and solution conductivity transients during one charge-discharge cycle of such an experiment are shown in Fig. 6. Cations and anions were held in the electric double layers formed at the extensive surfaces of the carbon aerogel cathodes and anodes during charging and released back into the electrolyte during discharge. Consequently, the salt concentration dropped during charging and increased during discharge. As expected, the outlet conductivity dropped more quickly than the inlet conductivity during deionization (charging). Similarly, the outlet concentration increased more quickly than the inlet conductivity during regeneration (discharge). Here too the failure of the current to decay to zero is attributed to parasitic electrochemical reactions or current leakage across gaskets and spacers. Transients in solution conductivity during batch-mode experiments with $\mathrm{NaCl}$ at four different applied voltages, 0.6, 0.8, 1.0, and 1.2 $\mathrm{V}$ are shown in Fig. 7. As expected, the greater the cell voltage, the greater the extent of deionization. The process was very effective at $1.2 \mathrm{~V}$, with much poorer performance at $0.6 \mathrm{~V}$. The electrosorption capacity of the carbon aerogel electrodes decreased as the cell voltage was lowered. The oscillations in the outlet conductivity during discharge are real and are believed to be due to concentration feedback effects. Note that the residence time of the loop is only 4 minutes, about the same as the period of the oscillation. A transient in solution conductivity during a single-pass experiment without recycle is shown in Fig. 8. The amplitude of the applied voltage was $1.0 \mathrm{~V}$ and the flow rate was $15 \mathrm{ml} / \mathrm{min}$. The conductivity dropped to a level below $1 \mu \mathrm{mho} / \mathrm{cm}$ after application of a voltage of $1.2 \mathrm{~V}$ across adjacent electrodes, representing a $99 \%$ removal of salt from the flowing stream. After 10 hours of operation, the carbon aerogel became saturated with $\mathrm{NaCl}$ (fully charged) and breakthrough was observed. The behavior is analogous to that of ion exchange columns.

Experiments were also conducted with a solution of $\mathrm{NaNO}_{3}$ in water that had an initial conductivity slightly greater than $100 \mu \mathrm{mho} / \mathrm{cm}$ (approximately $100 \mathrm{ppm}$ ). Once again a stack of 192 pairs of carbon aerogel electrodes was used. During batch-mode experiments with complete recycle, the amplitude of the applied voltage pulse was $1.0 \mathrm{~V}$, the volume of electrolyte was 4.0 $\mathrm{L}$, and the flow rate through the stack of electrodes was $1.0 \mathrm{~L} / \mathrm{min}$. Voltage, current, and solution conductivity transients during one charge-discharge cycle are shown in Fig. 9. A transient in solution conductivity during batch-mode experiments with four different applied voltages, 0.6 , $0.8,1.0$, and $1.2 \mathrm{~V}$ are shown in Fig. 10. It appears that slightly less $\mathrm{NaNO}_{3}$ is removed at the given voltages than in similar experiments with $\mathrm{NaCl}$. Another transient in solution conductivity during a single-pass experiment without recycle is shown in Fig. 11. The amplitude of the applied 
voltage was $1.0 \mathrm{~V}$ and the flow rate was $15 \mathrm{ml} / \mathrm{min}$. As in the case with $\mathrm{NaCl}$, the conductivity dropped to a level below $1 \mu \mathrm{mho} / \mathrm{cm}$ after application of a voltage of $1.2 \mathrm{~V}$ across adjacent electrodes, once again representing a 99\% removal of salt from the flowing stream. After 6 hours of operation, the carbon aerogel became saturated with $\mathrm{NaNO}_{3}$ (fully charged) and breakthrough was observed. The carbon aerogel electrodes seems to have slightly less capacity for $\mathrm{NaNO}_{3}$ than for $\mathrm{NaCl}$.

\section{Discussion}

If fully developed, CDI with carbon aerogel electrodes could have several important applications. As previously discussed, this technology could be used for the removal of various ions from waste water without the generation of acid and base secondary wastes. This may be especially important in cases involving radionuclides. At the present time, the United States Department of Energy has an inventory of approximately one billion liters of $\mathrm{NaNO}_{3}$ solution contaminated with

${ }^{137} \mathrm{Cs}$, ${ }^{90} \mathrm{Sr}$, and other radioactive materials. This technology could also be used for the treatment of boiler water for nuclear and fossil-fired power plants. Such water is now treated with ion exchange to remove ionic contaminants such as $\mathrm{Mg}^{+2}, \mathrm{Ca}^{+2}, \mathrm{Cu}^{+2}$, and $\mathrm{Cl}^{-}$. Elimination of these impurities is essential for the prevention of pitting, stress corrosion cracking, and scaling of heat transfer surfaces. CDI could be used to replace ion exchange systems used for the production of high-purity water for semiconductor processing. In addition to removing conductivity without the addition of other chemical impurities, the system probably removes small suspended solids by electrophoresis. Furthermore, organic impurities will chemisorb to the carbon. A typical electroplating process involves immersing an object to be electroplated into an electrolyte which contains dissolved metals such as nickel, cadmium, zinc, copper, silver, or gold, as well as a variety of salts. After the electroplating process is completed, the plated object is rinsed to remove residual electroplating solution and associated contaminants. Consequently, the rinse water becomes contaminated, creating a major environmental problem for the metal finishing and printed circuit board industry. At the present time, ion exchange is used for the treatment of such rinse water. CDI could provide advantages here as well. It could also be used to soften home drinking water without the introduction of sodium chloride. A typical domestic water softener uses sodium chloride to regenerate a bed of ion exchange resin. Downstream of the ion exchanger, $\mathrm{RO}$ is used to remove the sodium chloride introduced during regeneration. A CDI system would not require salt additions for regeneration and would not have to be followed by RO. CDI would also remove heavy metal and organic contaminants from the water. The energy efficiency of such a process and the lack of troublesome membranes could make such a process a contender for desalinating sea water and treating water for irrigation in the Central Valley of California. The minimum theoretical work required by an isothermal process to separate sea water, which is essentially a 3.5 weight percent solution of $\mathrm{NaCl}$ in water, into a saturated brine solution and a stream of $10 \mathrm{ppm}$ drinking water is calculated to be approximately $16 \mathrm{cal} / \mathrm{mol}(4.2$ $\mathrm{Wh} / \mathrm{gal}$ ) by the authors, assuming that the $\mathrm{NaCl}$ obeys the Debye-Huckel activity coefficient model $[28,29]$. The energy required by $\mathrm{CDI}$, approximately $\mathrm{QV} / 2$ where $\mathrm{Q}$ is the stored electrical charge and $V$ is the voltage between adjacent electrodes, is approximately eight times ( $8 \mathrm{X})$ the theoretical minimum. If any of the stored electrical energy is reclaimed during regeneration, or electrical discharge, the energy requirement could be reduced to a level well below $\mathrm{QV} / 2$, and perhaps even below QV/4 provided that voltage conversion devices are employed. Of course, this 
assumes that parasitic electrochemical charge-transfer reactions, leakage currents, and ohmic losses are minimized to the extent possible. Such low energy requirements make this process more attractive than thermal processes and extremely competitive with the best known RO systems.

\section{Future Work}

Parametric studies should be performed with other salts, as well as acidic and basic electrolytes. Higher concenetrations should be explored. A CDI system that consists of two stacks of aerogel electrodes in parallel should be built and tested. Such a system will enable one stack to be regenerated (discharged) while the other deionizes (charges). This mode of operation, potentialswing electrosorption, is analogous to pressure-swing gas absorption. During such operation, a portion of the current produced during regeneration should be used for purification so that the overall energy efficiency of the process is improved. Chromatographic separation of ions should be attempted. Theoretically, the system should have ionic selectivity, depending upon the size, charge, and complexation of the ions being separated. This is supported by the observed difference in breakthrough times for $\mathrm{NaCl}$ and $\mathrm{NaNO}_{3}$. Though $\mathrm{Cl}^{-}$and $\mathrm{NO}_{3}{ }^{-}$anions have the same charge, they have different sizes and degrees of complexation. These initial parametric studies have not provided sufficient data for conclusive statements about the performance of the electrodes over extended periods of times (years). Aging tests should be performed to determine the effects of voltage cycling on electrosorption capacity. Ultimately, the number of electrodes should be increased so that the continuous desalination of sea water can be demonstrated. In such applications, this technology may have the potential to enhance the general standard of living in areas with limited water of poor quality.

\section{Conclusions}

The capacitive deionization (CDI) of aqueous solutions of $\mathrm{NaCl}$ and $\mathrm{NaNO}_{3}$ with carbon aerogel electrodes has been demonstrated for the first time. Cell voltages ranging from 0 to $1.2 \mathrm{~V}$ were investigated. The best performance (salt removal) was achieved at $1.2 \mathrm{~V}$. In experiments without recycle, $99 \%$ of the salt in a $100 \mu \mathrm{mho} / \mathrm{cm}$ feed stream was removed until saturation of the carbon aerogel electrodes was reached. This particular CDI process offers numerous potential advantages over conventional thermal and membrane processes and deserves further investigation.

\section{Acknowledgments}

Funding for this project was provided by the Strategic Environmental Research and Development (SERDP) Program. This work was done under the auspices of the U.S. Department of Energy (DOE) by Lawrence Livermore National Laboratory (LLNL) under Contract No. W-7405-Eng-48.

\section{References}

1. Trainham, J. A., Newman, J., "Flow-Through Porous Electrode Model: Application to Metal-Ion Removal from Dilute Streams," J. Electrochem. Soc. 12410 (1977) 1528-1540. 
2. Van Zee, Newman, J., "Electrochemical Removal of Silver Ions from Photographic Fixing Solutions Using a Porous Flow-Through Electrode," J. Electrochem. Soc. 1245 (1977) 706-708.

3. Moeglich, K., “Apparatus for Removal of Contaminants from Water," U. S. Pat. No. 4,072,596, February 07, 1978.

4. Blaedel, W. J., Wang, J. C., "Flow Electrolysis on a Reticulated Vitreous Carbon Electrode," Anal. Chem. $\underline{11} 7$ (1979) 799-802.

5. Risch, T., Newman, J., "Flow-Through and Flow-By Porous Electrodes at the Limiting Current," J. Electrochem. Soc. 13111 (1984) 2551-2556.

6. Lessner, P.; Newman, J., "Hydrodynamics and Mass Transfer in a Porous-Wall Channel," J. Electrochem. Soc. 1318 (1984) 1828-1831.

7. Platek, G. F., "Reticulate Electrode for Recovery of Metal Ions," U. S. Pat. No. 4,515,672, May 07, 1985.

8. Matlosz, M., Newman, J., "Experimental Investigation of a Porous Carbon Electrode for the Removal of Mercury from Contaminated Brine,". J. Electrochem. Soc., 1339 (1986) 1850-1859.

9. Caudle, D. D., Tucker, J. H., Cooper, J. L., Arnold, B. B., Papastamataki, A., "Electrochemical Demineralization of Water with Carbon Electrodes," Research Report, Oklahoma University Research Institute, May 1966, 205 p.

10. Murphy, G. W., Bloomfield, J. J., Smith, F. W., Neptune, W. E., Caudle, D.D., "Demineralization of Saline Water by Electrically-Induced Adsorption of Porous Carbon Electrodes," Oklahoma University Research Institute.

11. Johnson, A. M.; Venolia, A. W.; Newman, J., Wilbourne, R. G.; Wong, C. M.; Gillam, W. S., Johnson, S., Horowitz, R. H., "Electrosorb Process for Desalting Water," Office of Saline Water Research and Development Progress Report No. 516, U.S. Dept. Interior Pub. 200 056, March 1970, 31 p.

12. Johnson, A. M., Venolia, A. W., Wilbourne, R. G., Newman, J., "The Electrosorb Process for Desalting Water," Marquardt Co., Van Nuys, CA, March 1970, 36 p.

13. Johnson, A. M., "Electric Demineralizing Apparatus," U.S. Pat. No. 3,755,135, August 28, 1973.

14. Johnson, A. M., Newman, J., "Desalting by Means of Porous Carbon Electrodes," J. Electrochem. Soc., 1183 (1971) 510-517.

15. Oren, Y., "Electrochemical Parametric Pumping," Ph.D. Dissertation, Weizmann Inst. of Science, Rehovoth, Israel, March 1983, 111 p.

16. Oren, Y.; Soffer, A., "Water Desalting by Means of Electrochemical Parametric Pumping: II. Separation Properties of a Multistage Column," J. Appl. Electrochem. 134 (1983) 
489-505.

17. Oren, Y., Soffer, A., "Water Desalting by Means of Electrochemical Parametric Pumping: I. The Equilibrium Properties of a Batch Unit Cell," J. Appl. Electrochem. 134 (1983) 473-487.

18. Katsu, Keitaro, "Double Layer Electric Capacitor," Nippon Electric Co., Jap. Pat. Appl. 91-303689.

19. "Electric Double-layer Capacitor," Matsushita Electric Industrial Co., Ltd., Jap. Pat. Appl. 83-89451.

20. Tabuchi, J., Kibi, Y., Saito, T., Ochi, A., "Electrochemical Properties of Activated Carbon/Carbon Composites for Electric Double-layer Capacitor in New Sealed Rechargeable Batteries and Supercapacitors," presented at the 183rd Electrochem. Soc. Mtg., Honolulu, HI, May 16-21, 1993.

21. "Electrical Double-layer Capacitor, Uses Porous Polarized Electrode Consisting of Carbonized Foamed Phenol Resin," Mitsui Petrochem Ind.; Jap. Pat. Appl. 89-210642.

22. Delnick, F. M., Ingersoll, D., Firsich, D., "Double-layer Capacitance of Carbon Foam Electrodes," SAND-93-2681, Sandia National Laboratory, Albuquerque, NM, 1993, 10 p.

23. Mayer, S. T., Pekala, R. W., Kaschmitter, J. L., "The Aerocapacitor: An Electrochemical Double-layer Energy-Storage Device," J. Electrochemical Society 1402 (1993) 446-451.

24. Wessling, B, Volk, H., Hilleberg, M., Funder, C., Siemers, O., Merkle, H., "Stable Electrode for Electrolytic Process (Desalination and Drying) Contains Thermoplastic Polymer and Material Giving conductivity and Stable Potential," U. S. Pat. No. 4806212.

25. Campbell, D.O., Collins, E.D., King, L.J., Knauer, J.B., "Process improvement studies for the Submerged Demineralizer System (SDS) at the Three Mile Island Nuclear Power Station, Unit 2," ORNL/TM-7756, Oak Ridge National Laboratory, Oak Ridge, TN, May $1982,30 \mathrm{p}$.

26. Wang, J., et al., "Carbon Aerogel Composite Electrodes," Anal. Chem. 65 (1993) 23002303.

27. Pekala, R. W., et al., "Supercapacitors Based on Carbon Foams," U.S. Pat. No. 5,260,855.

28. King, C. J., Separation Processes, 2nd Ed., McGraw-Hill, San Francisco, CA, 1980, pp. 661-664.

29. Newman, J. S., Electrochemical Systems, 2nd Ed., Prentice Hall, Englewood Cliffs, NJ, 1991, pp. 89-94. 


\section{Figure Captions}

Fig. 1. Schematic representation of the CDI of salty water with two carbon aerogel electrodes.

Fig. 2a. Photograph of single carbon aerogel electrode supported on a sheet of titanium.

Fig. 2b. Photograph showing a lower stainless steel header with a rubber gasket and threaded rods; an array of electrodes, gaskets and spacers; and an upper stainless steel header.

Fig. 2c. Photograph showing the assembly of components appearing in Fig. $2 \mathrm{~b}$ into a stack.

Fig. 3. Photograph of system used for batch-mode demonstration of the CDI process.

Fig. 4. Schematic of system used for batch-mode demonstration of the CDI process.

Fig. 5. Batch-mode experiment with $7.5 \mu$ mhos $/ \mathrm{cm} \mathrm{NaCl}$ solution.

Fig. 6. Batch-mode experiment with $100 \mu \mathrm{mho} / \mathrm{cm} \mathrm{NaCl}$ solution.

Fig. 7. Effect of cell voltage on the electrosorption of $\mathrm{NaCl}$.

Fig. 8. Single-pass experiment with $100 \mu \mathrm{mho} / \mathrm{cm} \mathrm{NaCl}$ solution.

Fig. 9. Batch-mode experiment with $100 \mu \mathrm{mho} / \mathrm{cm} \mathrm{NaNO}_{3}$ solution.

Fig. 10. Effect of cell voltage on the electrosorption of $\mathrm{NaNO}_{3}$.

Fig. 11. Single-pass experiment with $100 \mu \mathrm{mho} / \mathrm{cm} \mathrm{NaNO} \mathrm{Nal}_{3}$ solution. 


\section{Carbon Aerogel CDI Process}

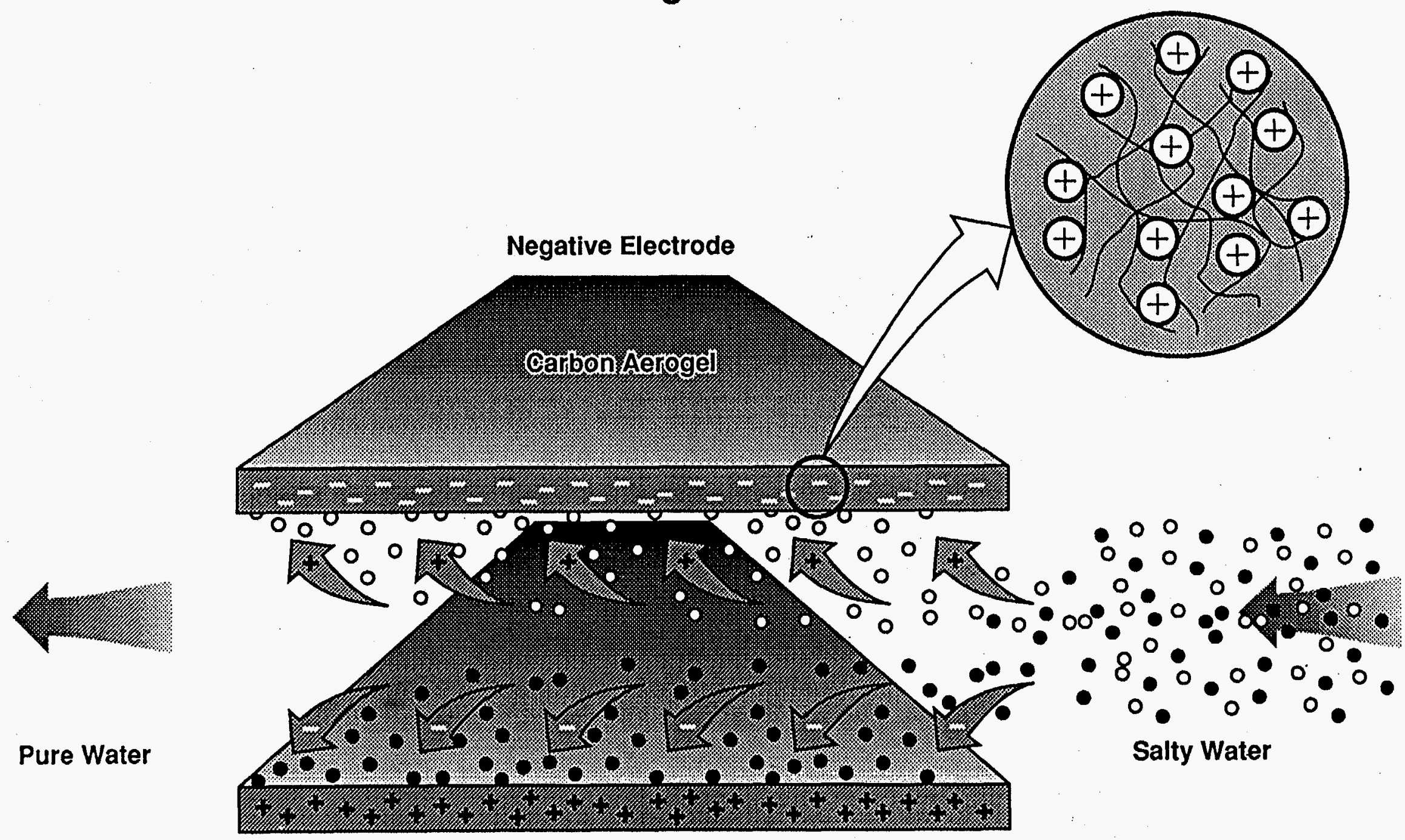

Positive Electrode

Fig. 1. Schematic representation of the CDI of salty water with two carbon aerogel electrodes. 


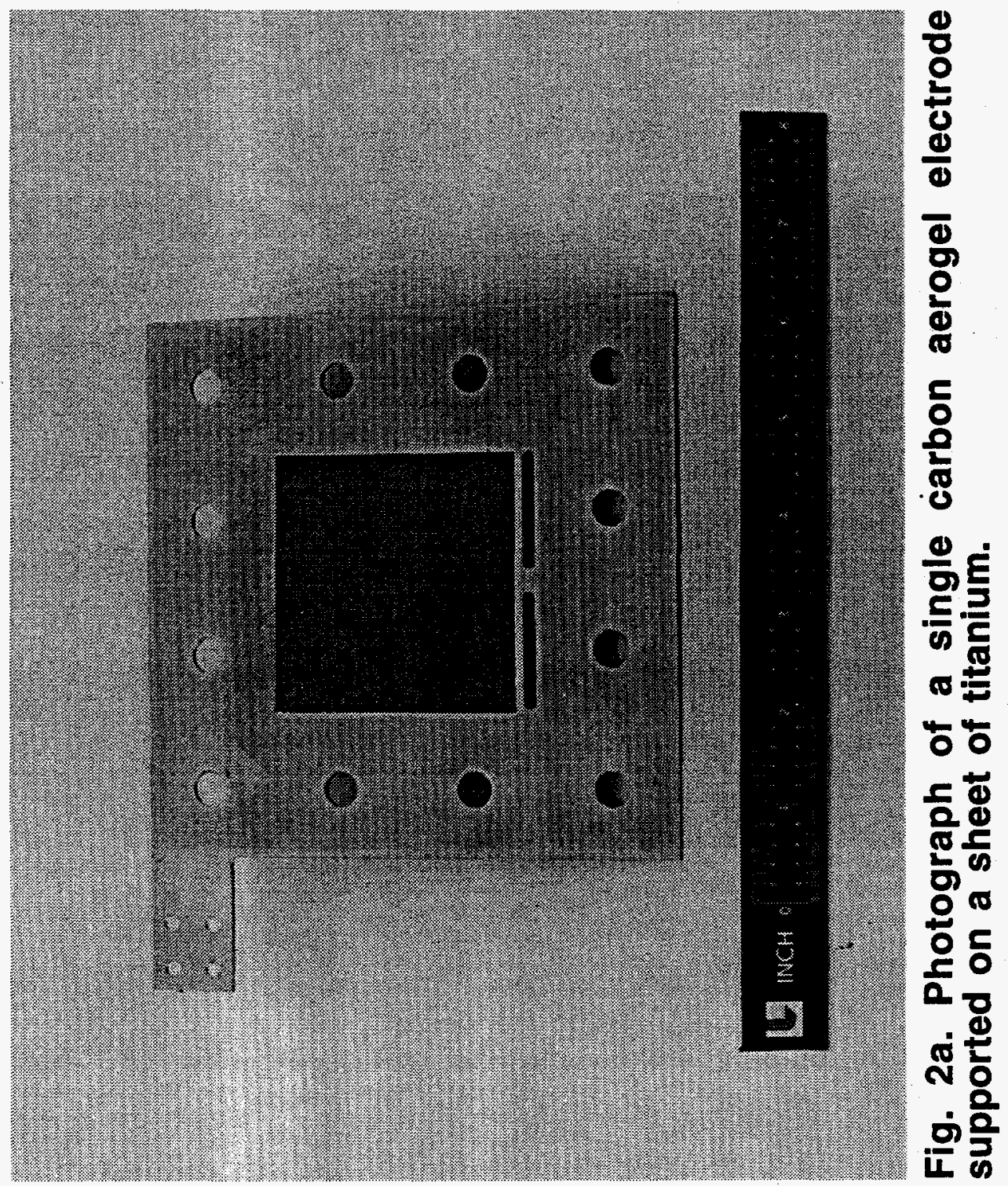




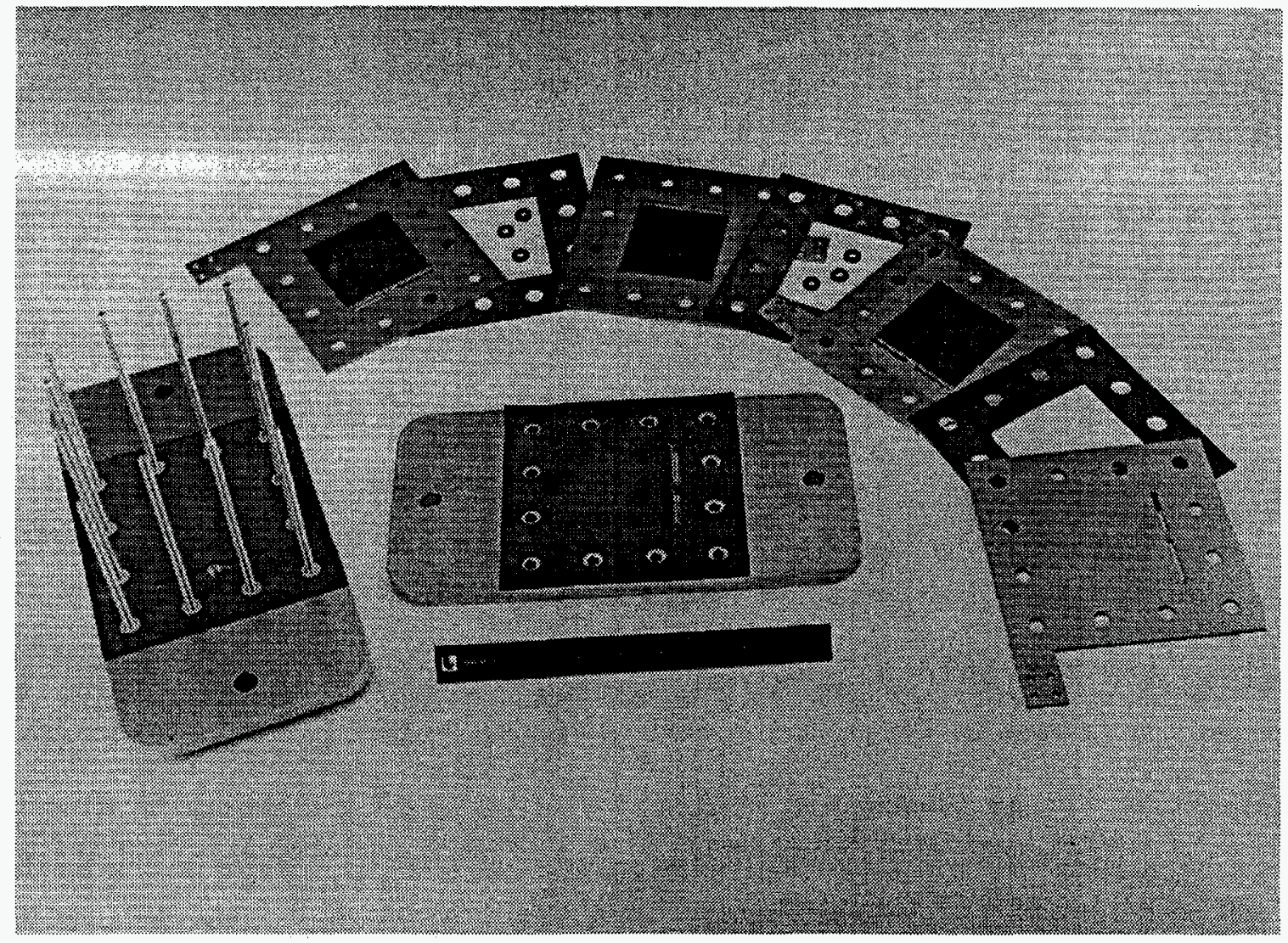

Fig. 2b. Photograph showing a lower stainless steel header with a rubber gasket and threaded rods; an array of electrodes, gaskets, and spacers; and an upper stainless steel header. 
-yoets e olu! qz 6 |y u! Gu!deedde

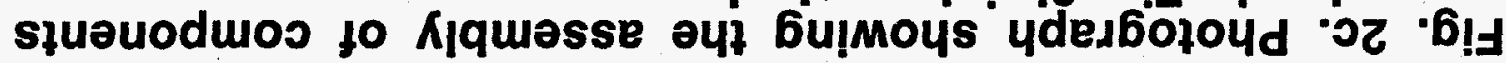

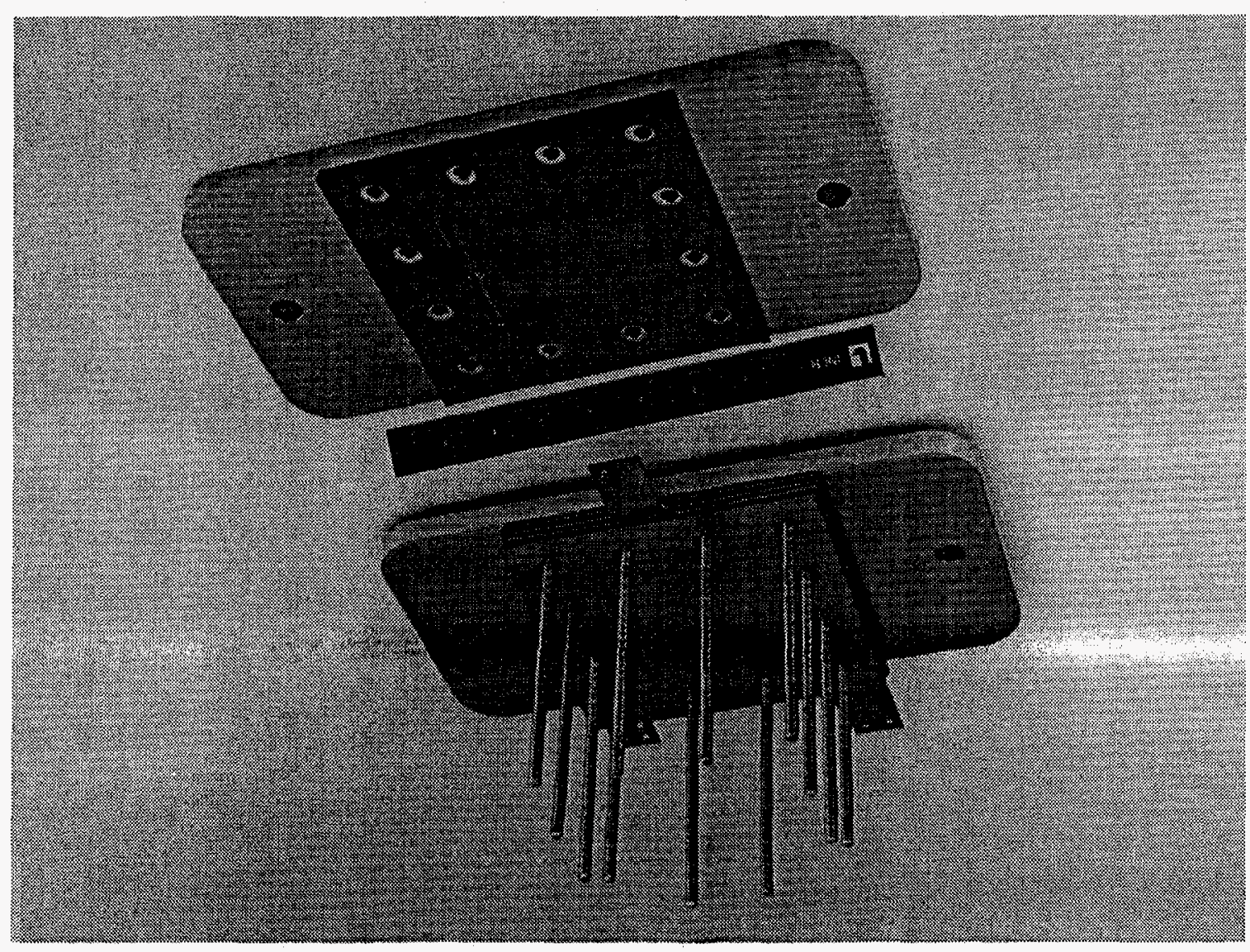




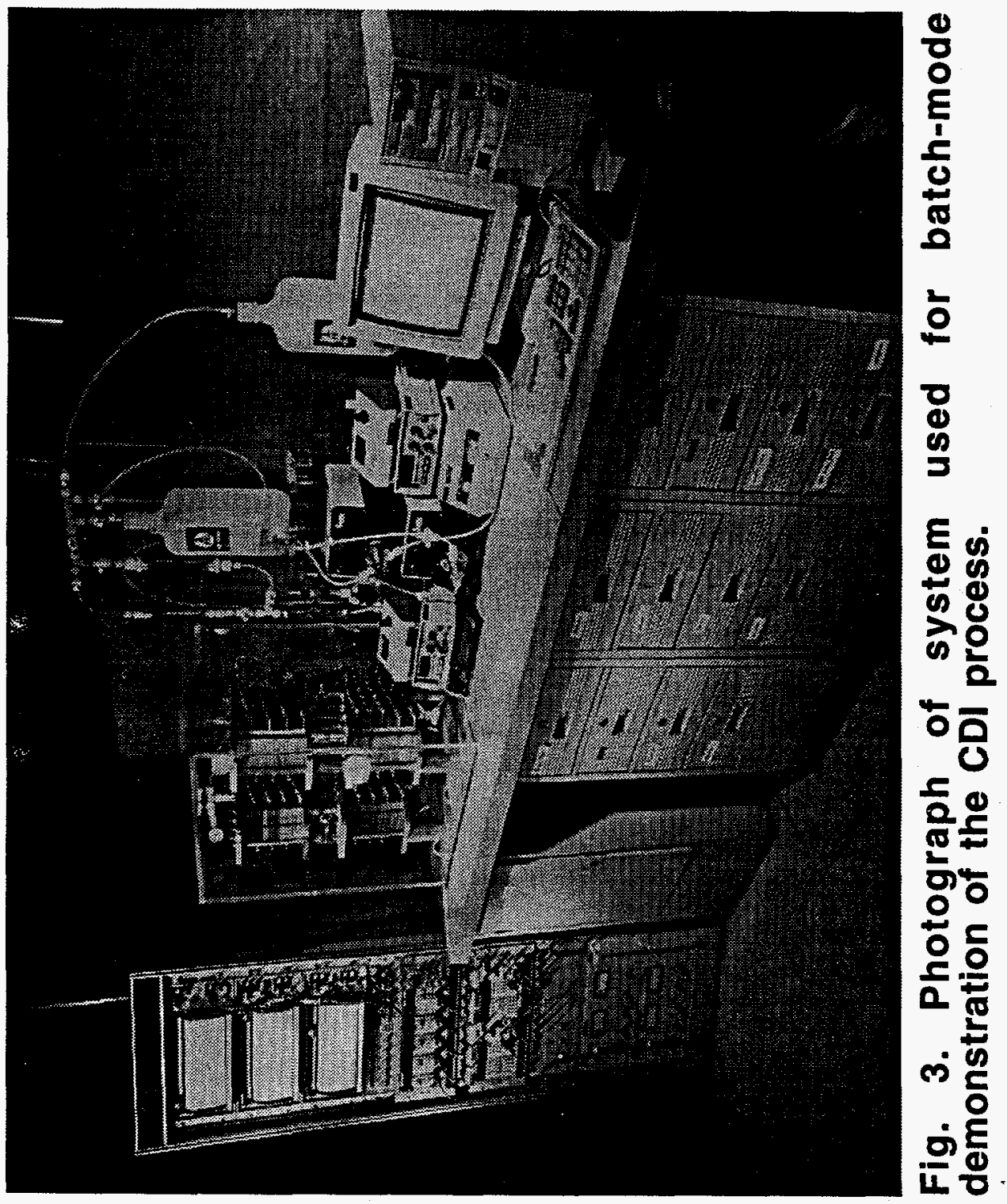




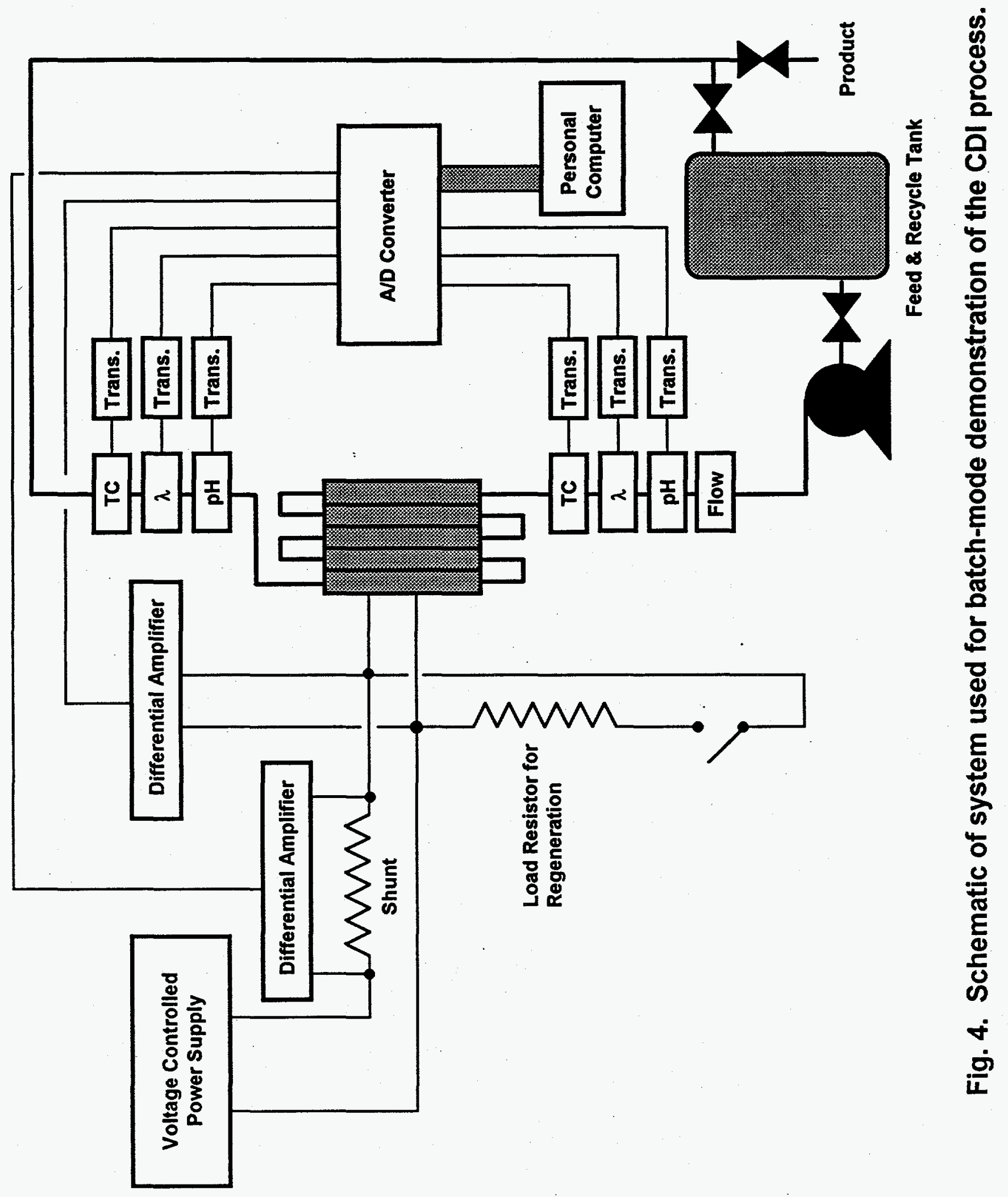




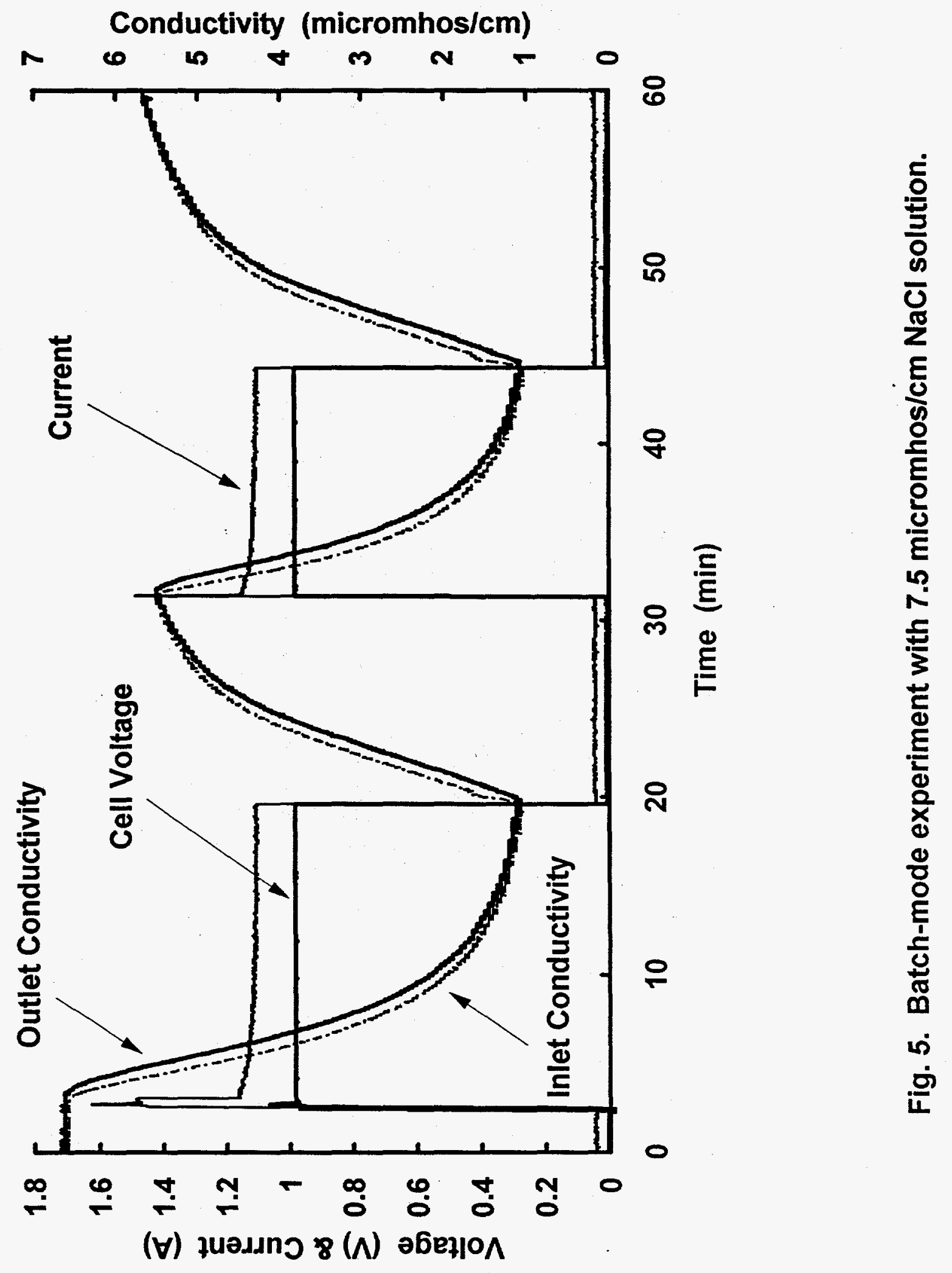




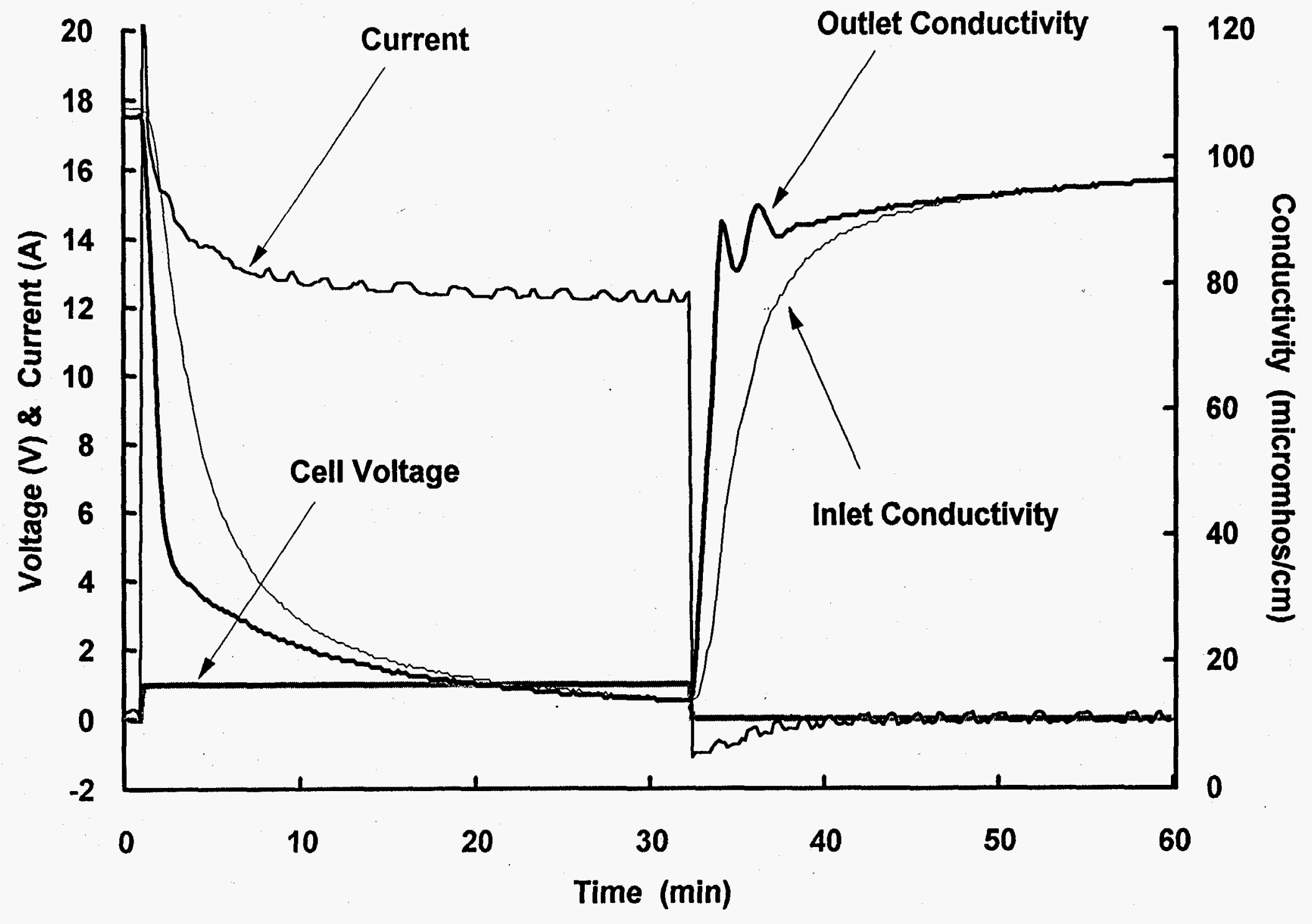

Fig. 6. Batch-mode experiment with 100 micromho/cm NaCl solution. 


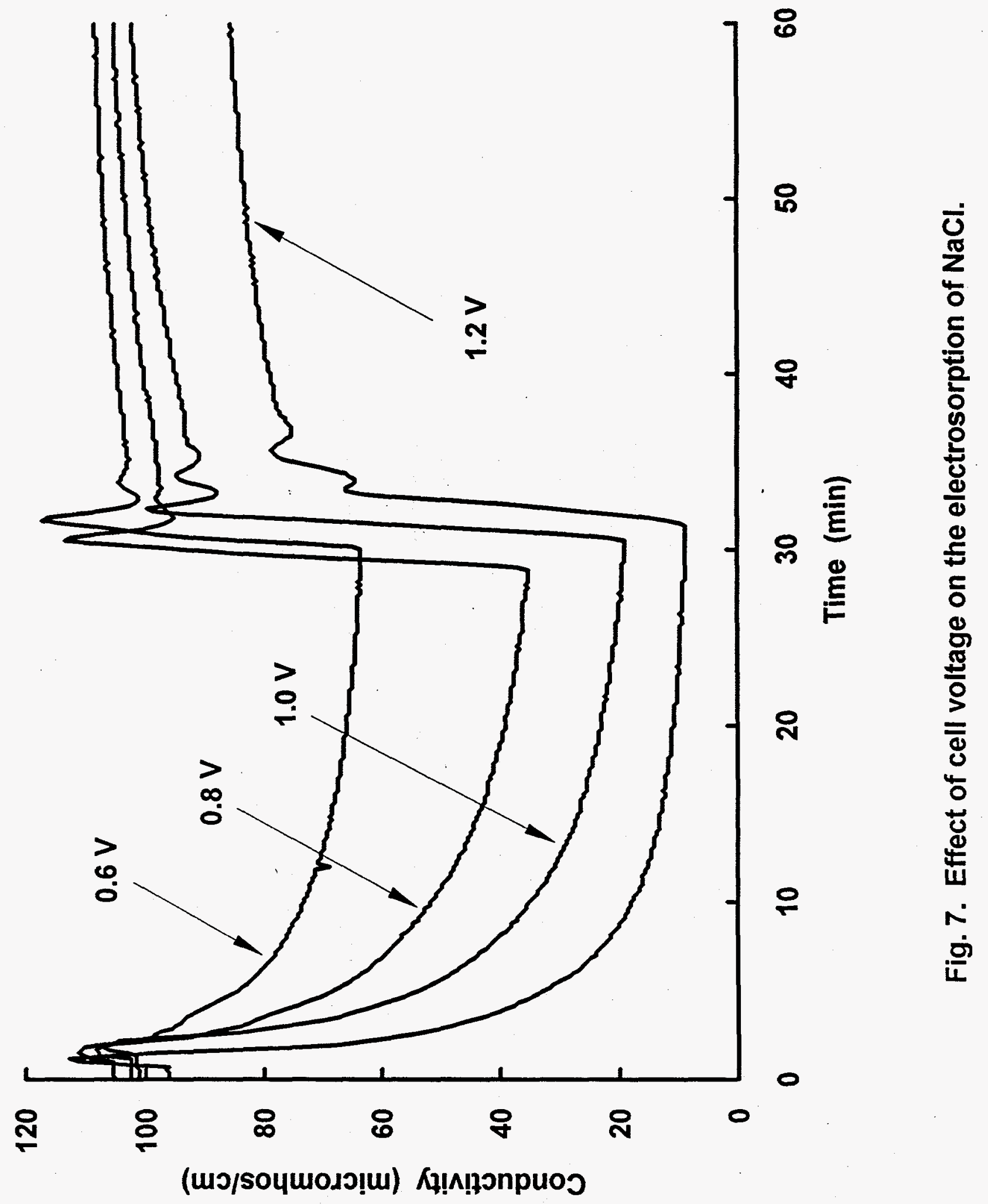




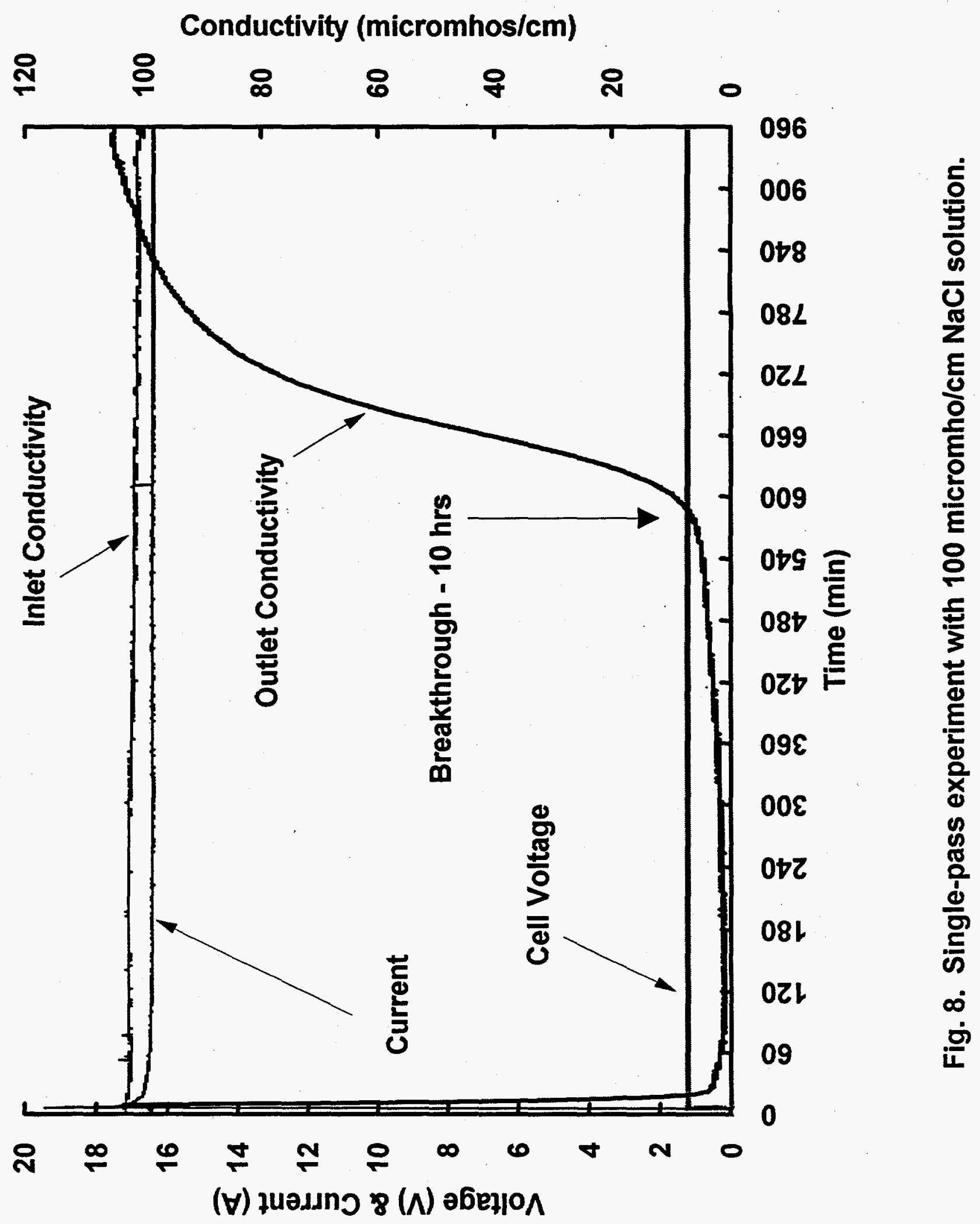




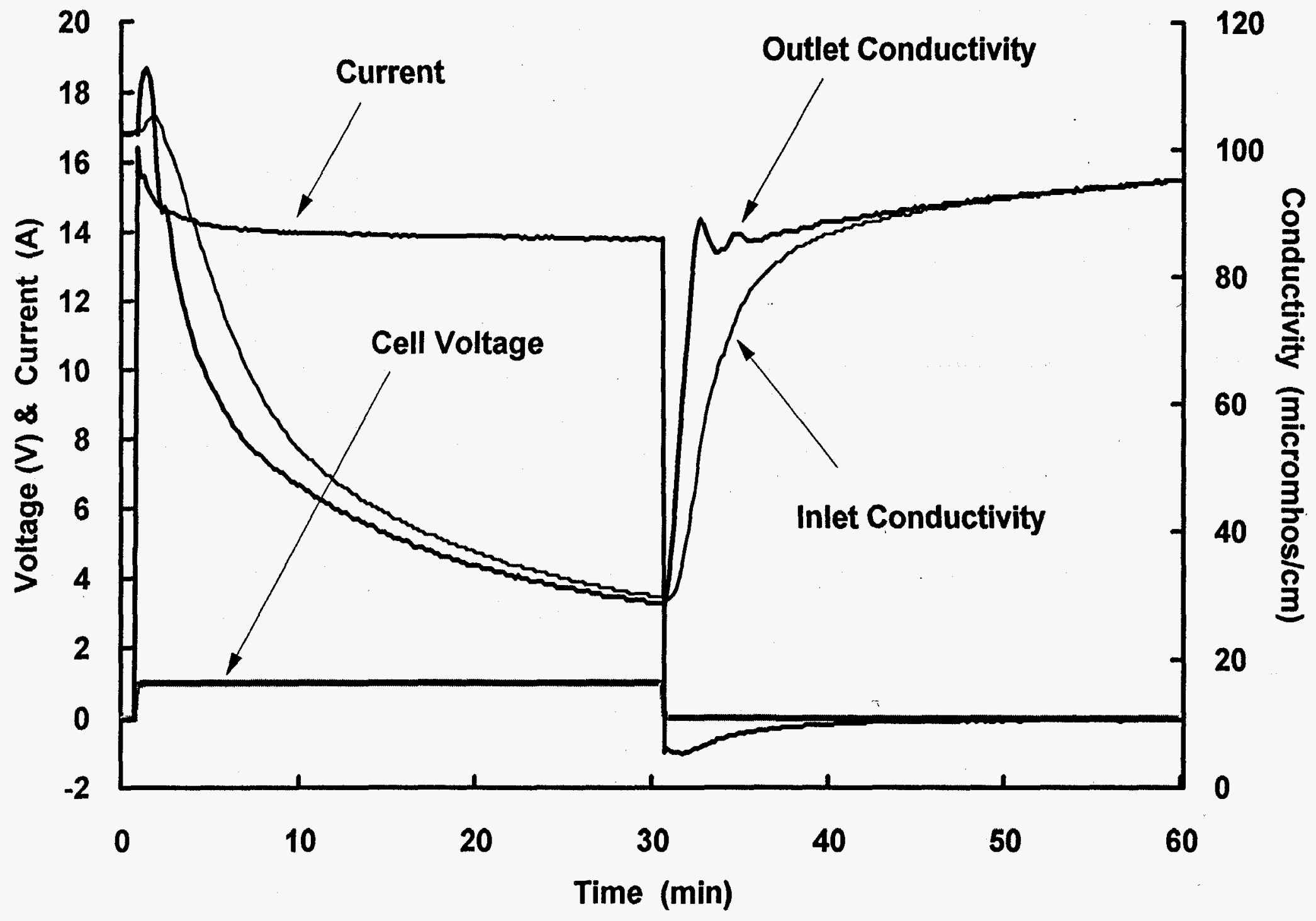

Fig. 9. Batch-mode experiment with 100 micromho/cm NaNO3 solution. 


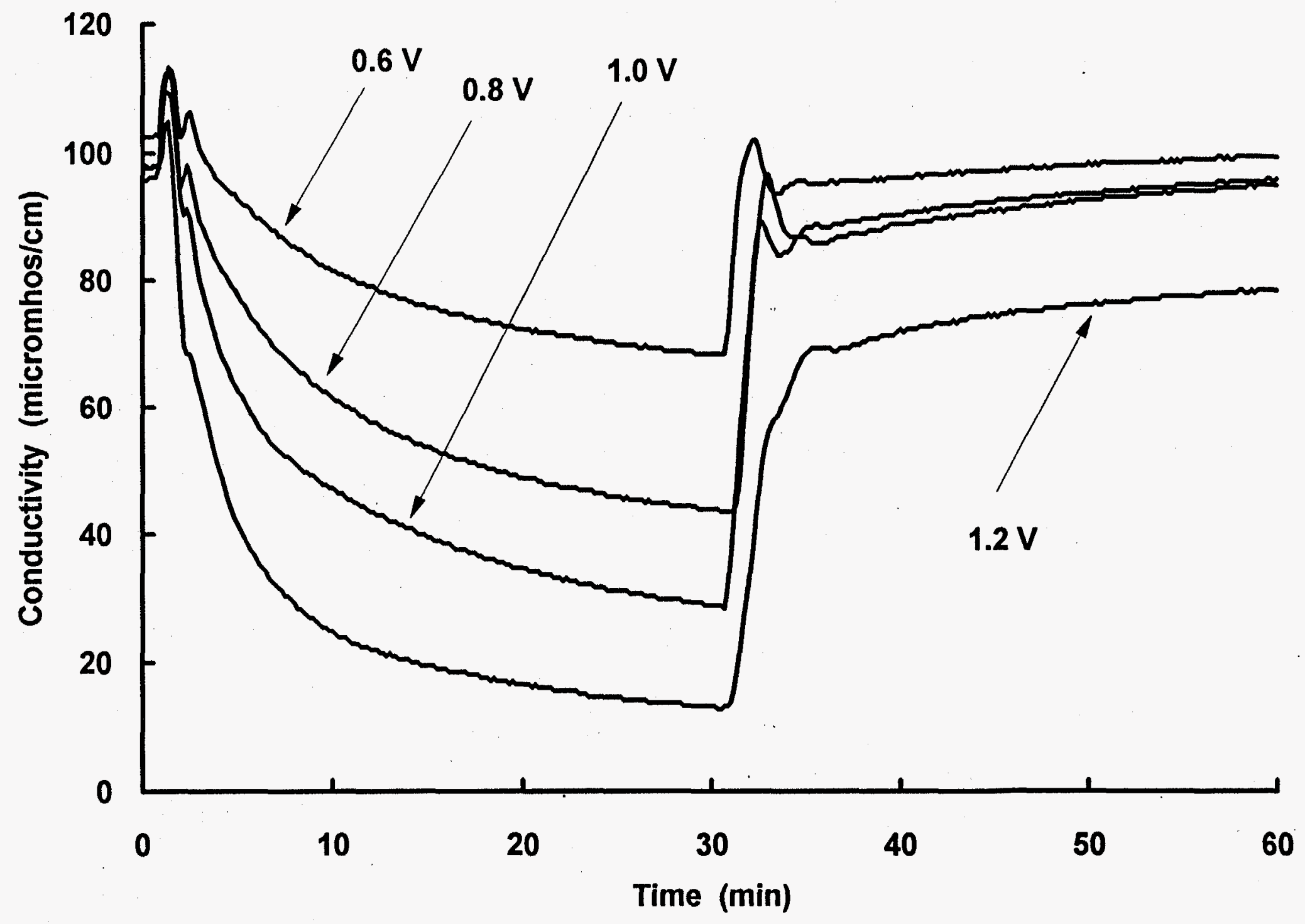

Fig. 10. Effect of cell voltage on the electrosorption of $\mathrm{NaNO}$ 


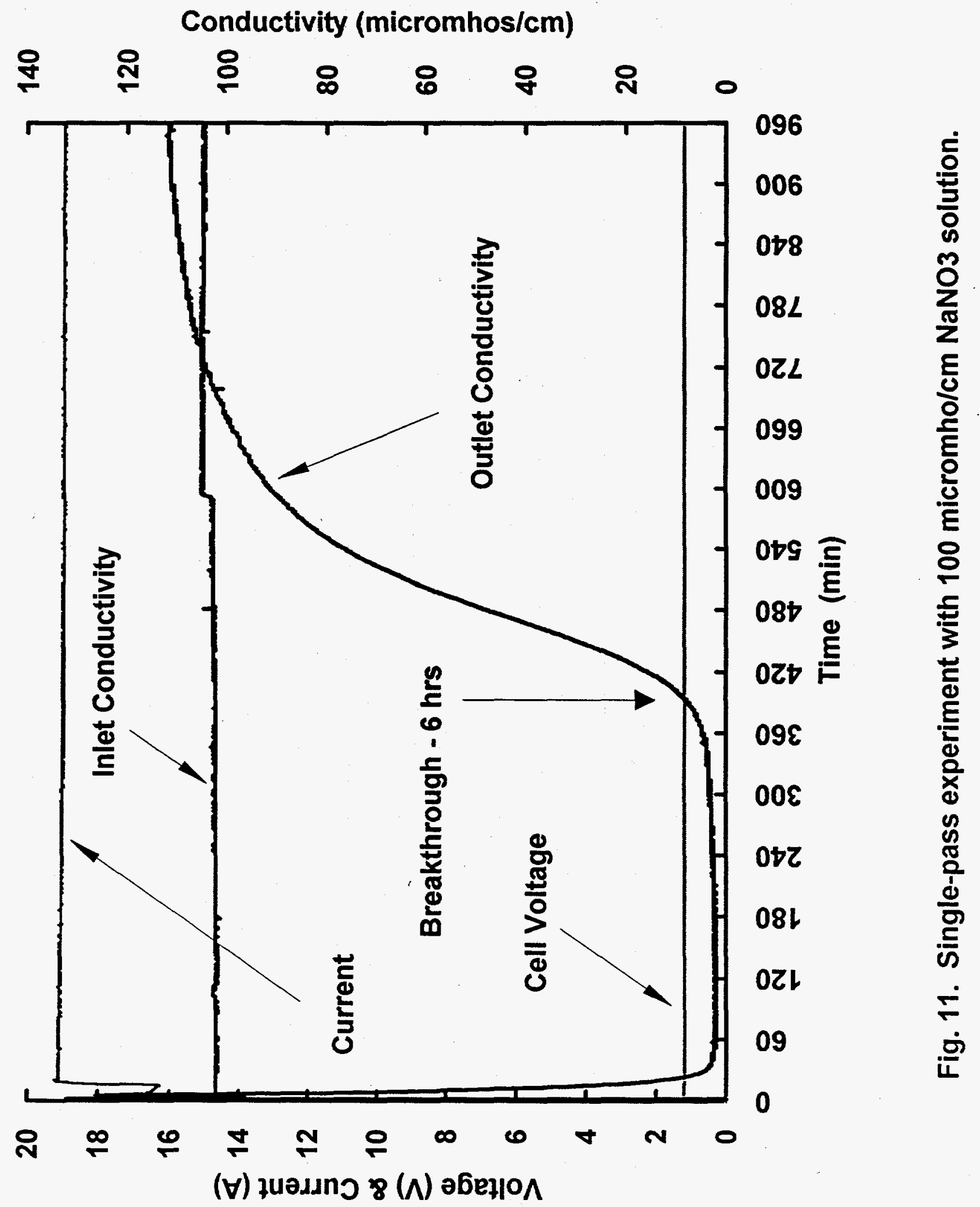

